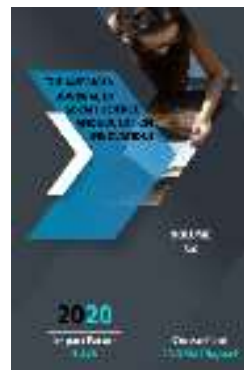

Journal Website: http://usajournalshub.c om/index,php/tajssei

Copyright: Original content from this work may be used under the terms of the creative commons attributes 4.0 licence.

\section{Sociolinguistic Analysis Of Court Speech}

\author{
Dilora Abduhamidovna Nabiyeva \\ Doctor Of Philology, Professor, Andijan State University, Uzbekistan
}

Khurmatillo Tolqinjon Ogli Ismailov

PhD Student, Andijan State University, Uzbekistan

\title{
ABSTRACT
}

This article discusses and illuminates the sociolinguistic analysis of Court Speech. Language and thinking, language and society, language and culture relations today are engaged in the study of problems in linguistics, such as psycholinguistics, sociolinguistics, pragmalinguistics, lingvocultrology, cognitive linguistics and their interdependent relationship. Unlike systemic linguistics, the fact that speech activity is the most important object of linguistic research, which has become a prelude to new perspectives, new interpretations, leads to the emergence of topical scientific problems and views as linguistics develops. In this sense, the study of the speech phenomena of linguistic units in linguistics in the sociolinguistic direction, the study of the state of speech in relation to social status, provided an opportunity to conduct sociolinguistic research in Uzbek linguistics. According to Professor Mahmudov, the direction of sociolinguistics in world linguistics, or rather the science, has emerged as a result of a comprehensive understanding of the strong connection between language and society, the understanding of the many intersecting points of linguistics and sociology [1.13]. The above issues are covered in the article.

\section{KEYWORDS}

Psycholinguistics, sociolinguistics, pragmalinguistics, lingvocultrology, cognitive linguistics, Court Speech.

\section{INTRODUCTION}

If we look at the development of the field of sociolinguistics in world linguistics, we can see that a number of studies have been conducted and these studies have revealed the social features of language. In particular, by Yu.Desheriev, A.D.Shveitser, L.B.Nikolsky, 
V.D.Bondaletov, R.T.Bell, L.P.Krisin, I.H.Musin, V.I.Belikov, S.V.Krilenko research focuses on issues such as language and society, language policy. As a result of research, we can observe that in recent years the attention of sociolinguists has been focused on the speech of various social groups in society. In this regard, in particular, the researchs of Yu.K.Voloshin, N.K.Shulikin, T.A.Ivushkina, A.G.Kostetskaya, D.V.Kryukov, Yu.O.Kvartovkina, E.A.Levina, P.V.Ermakova, N. N.Kopitina, V.S.Anoxina, A.V.Ovchinnikova are great importance.

At the same time, Uzbek linguistics has begun to conduct research on the basis of new scientific paradigms of world linguistics, to expand the use and research of our language, to develop it in all respects. This process can also be seen in the fact that linguistic research today pays special attention to aspects of speech phenomena related to the owner of the language (speech). In recent years, representatives of the sociolinguistic field have been interested in the features of the practical use of language units of representatives of certain societies.

Despite the emphasis on linguistic or sociological issues in the problem of "language and society", some scholars have noted the need to include it in the sociolinguistic or lingvosociological aspects. In the sociolinguistic approach, signs and character complexes, their place in the diasystem, etc., and in the lingvosociological approach, sociological categories (social group, social status of the individual) are the main points [ 2 . 5]. Based on this, scholars emphasize the existence of sociolinguistics and sociology of language.

\section{THE MAIN FINDINGS AND RESULTS}

It is known that the term sociolinguistics was first used in linguistics in 1952 by the American researcher H. Curry [3. 10]. In the 1920s and 1930s, Russian linguists studied the science under two different names. Terms such as sociolinguistics, came into being in connection with the psyche of that period. Later, more precisely in the 50s, the science called sociolinguistics came to the fore. The fact that language is closely connected with life, with society, is in fact based on the relationship between language and society, as well as the emergence of national traditions and national values is consistent with the essence of the concept of sociolinguistics [4. 4]. This is due to his study of the universal and political features of language as a science, as well as the relationship between language and society, language and ideology, language and thinking, language and people, language and age, language and sex, language and culture, as well as the philosophical features of language. depends on.

Professor H. Nematov in his book "Sociolinguistics" notes that one of the sharp differences between sociolinguistics and social linguistics is that it pays special attention to the conditions of speech - that is, the speech process. Sociolinguistics deals with speech and therefore the context of speech is one of the decisive factors for this direction [5. 46]". At the same time, sociolinguistics is developing, the main goal of which is to determine the constant correlations between language structures and social structures, the relationship between linguistic forms and social tasks and roles [1.13]".

If N.Mahmudov, M.Mirtojiev paid attention to the issues of language and society relations in Uzbek linguistics, 6] the valuable researches of 
Sh.Iskandarova, S.Muminov, M.Sulaymonov, K.Rasulov, M.Kurbanova, L.Raupova, H.Yuldasheva can be mentioned as a number of researches revealing socio-linguistic aspects of speech [7].

Sociolinguistics has the same direction as macrosociolinguistics and microsociolinguistics, while macrosociolinguistics is the study of the speech of different strata of society, while macrosociolinguistics studies the large-scale processes of language and social relations [8. 177]. Today in linguistics there is a growing study of linguistic processes and their speech patterns related to social groups in society, which is the object of study of microsociolinguistics, the study of language in relation to the "language owner", the study of speech phenomena by social strata and categories [2.8].

As Professor N.Mahmudov noted, not enough work has been done in sociolinguistics in Uzbek linguistics. Literary text has been the main source in sociolinguistic research in Uzbek linguistics. It is important to note that sociolinguists face the problem of studying live speech [2.12]. In this sense, in contrast to the literary text, in addition to observing the lively dialogue of the participants in the trial, we need to develop the ability to sociologinguistically analyze specific speech patterns and, on this basis, to accurately assess interpersonal relationships. The sociolinguistic analysis of court speech is also a practical manifestation of the same ideas above. It is very important to analyze the sociolinguistic analysis of court speech, which has a specific speech situation (conditions), as well as holistic and specific aspects based on legal requirements, along with the scope of communication and various forms of written speech in society.
Therefore, the disclosure of the sociolinguistic features of speech by court participants, including the adaptation of speech to social status, is one of the issues that need to be addressed theoretically and practically. It is important to study the speech expressions and working papers in the court on the basis of the sociolinguistic approach, to examine the social adaptation of language units on the basis of linguistic-speech principle, as well as to scientifically substantiate the speech adaptation in court in terms of social factors, speech conditions and speech situation. The sociolinguistic analysis of court speech in Uzbek linguistics has not been specifically studied so far. The trial is a specific area of debate in which the interests of the state and society, as well as the accused and the victim, are protected in accordance with universal moral norms, and the concepts of justice and truth are required to prevail. All means in this process, including speech, are aimed at the celebration of this justice and truth [9.144].

Different social positions in society, the speech of officials is also a peculiar privatization of language units. Sociolinguistics examines the state of language units in the speech of different strata of society, the role and functions of internal and external factors that provide it, the ability to evaluate others on the basis of speech, to relate, to understand the other's opinion, to present one's opinion to the speaker serves to create a specific theoretical basis for the development of mechanisms for the formation of skills [2.10]. This privatization is reflected in the speeches of the participants of the court session in a bright and unique way.

In general, it can be observed that the symptoms of social adaptation appear in the subject in three forms.

First, a person's appearance (dress) is limited by the position he or she holds in society. 
Second, the physiological state of an individual, i.e., his behavior, is automatically limited by his social status.

Third, a person's speech (use of language units specific to that circle) is also limited within its own status.

These characters can be grouped as follows:

1. Social adaptation of appearance.

2. Social adaptation of behavior.

3. Social adaptation of speech.

The bright manifestation of these adaptations is certainly observed under the influence of factors such as space, time, situation. The first group (social adaptation of appearance) may not be the same in all situations. The second and third groups (social adaptation of behavior; social adaptation of speech) appear in all situations complementing each other. These signs of social adaptation are most evident during a person's performance of a particular social task. In this sense, the court session can be considered as an area of discussion in which the three signs of social identity in individuals are clearly observed. Direct observation of live communication in court is important when thinking about important aspects of social adjustment. In this sense, we cannot say that these three groups are equally observed in each participant in the discussion. The presiding judge (judge), the public prosecutor (prosecutor), the defense attorney (lawyer) show signs of social identity in full, while the rest of the participants show signs of group 2-3.

Among the goals and objectives of sociolinguistics, the issue of the specificity of speech units under the influence of social factors (third group) occupies a central place. There are forms of appeal that are used at the beginning, continuation and end of the dialogue, which in a unique way show the signs of social adaptation of speech. According to Professor Sh. Iskandarova, the forms of appeal determine the social relations of the interlocutors on the basis of their socially regulating functions. Therefore, these language units are characterized by a high degree of social variability. Forms of communication, according to their methodological functions, represent the tone of communication, the functional area of communication. The form of appeal that appears at the beginning of the call determines the rhythm that is specific to the subsequent communication. In the appeal, the nomination of the person is often seen. Appeals often show signs such as the addressee's profession, position in the community in terms of service, age and gender[10. 65]. From these ideas it is understood several important aspects which the Appeal forms represent, in particular the Appeal forms:

1. Belonging to a social function;

2. Specificity of a certain style;

3. Nomination of the person represents.

Linguist B. Urinbaev says that in the Uzbek language there are words that express the vocative form and are used in people's appeals, which can be called vocative words. These types of vocabulary include words such as comrade, gentleman, critic, citizen, friend, companion, type. In such words, the call, the urge, the appeal is felt [10.66].

The above considerations suggest that it is important to observe appeal forms in uncovering the sociolinguistic aspects of court speech. The appeal of the interlocutors at the court hearing (regardless of their gender, age) to each other with certain (prescribed by law) vocative words reflects the above social 
function, specific style, nomination of the person. To interpret vocative words, we refer to Article 431 of the Code of Criminal Procedure. "The presiding judge announces the composition of the court, who is the public prosecutor, public prosecutor, defense counsel, public defender, who is the victim, civil plaintiff, civil defendant and who are their representatives, who is the clerk of the court, expert, specialist, interpreter. . "(Code of Criminal Procedure of the Republic of Uzbekistan, Article 231, part 1). Judges and people's deputies appointed or elected to this court shall participate in the consideration of a criminal case (Code of Criminal Procedure of the Republic of Uzbekistan, Art. 30). The composition of the court listed in these articles: such as the presiding judge, the public prosecutor, the public prosecutor, the defense counsel, the public defender and their representatives, the clerk of the court, the expert, the specialist, the interpreter and the people's counsel are named in the court session are vocative words. In addition, in court speeches, the words of the jury, the court and the participants in the court session are often used as a form of appeal. This is mainly seen in the speech of the public prosecutor and the defense counsel. "Negotiations of the public prosecutor K. Kamilov:

- Dear jury and participants of the court session! Criminal Code of the Republic of Uzbekistan. Article 223, part 2, item “b”, Article 246, part 2, Article 25 and part 273, part 5 ..." (from the minutes of the court session). Defense lawyer K.Kamilov's speech: - Dear participants of the court and the court session! K.Kamilova, who was defended by me at the court hearing today ..." (from the minutes of the court session). Defense lawyer K.Kamilov's speech: Distinguished members of the court and participants of the court session, today
K.Kamilov and others, who were under my protection after the investigation and court proceedings ... (from the minutes of the court session).

Research shows that the forms of appeal used by Uzbeks are largely determined by nine factors. These are such as 1. social affiliation; 2. profession (position, title); 3. acquaintance of the interlocutors; 4 . conditions of speech movement; 5 . age of communicators; 6 . their gender; 7 . place of residence; 8. methodological situation; 9. the nature of the communicators [10.67]. All of these factors can be equally important in reference forms in informal communication situations. However, as noted above, the court session and the dialogue in it, which are different from any other situation, are typical of the formal style, in which the forms of appeal expressed only in 2. profession (position, title (social role, position - I.X.)) 4. conditions of verbal movement factors are considered important. Social affiliation in court appeals; the unfamiliarity of the interlocutors; age of communicators; their gender; place of residence; methodological situation; factors such as the nature of the communicators will not be significant . The only "defendant" mentioned by the presiding judge! can be explained by the reference. 
The American Journal of Social Science and Education Innovations (ISSN - 2689-100x)

Published: August 25, 2020 | Pages: 253-260

Doi: https://doi.org/10.37547/tajssei/Volume02Issueo8-41

\begin{tabular}{|c|c|}
\hline Appeal view & Factors in the Application of Appeal Forms \\
\hline \multirow[t]{9}{*}{ Defendant! } & Significant \\
\hline & $\begin{array}{l}\text { social role - The accused is called a defendant in court, and after the } \\
\text { verdict is pronounced, he is called a convicted or acquitted (Code of } \\
\text { Criminal Procedure of the Republic of Uzbekistan, Article 45, part 2). }\end{array}$ \\
\hline & $\begin{array}{l}\text { verbal conduct conditions - Criminal proceedings in court are conducted } \\
\text { only in respect of the accused. (Code of Criminal Procedure of the } \\
\text { Republic of Uzbekistan, Article 414, part 1). }\end{array}$ \\
\hline & Insignificant. \\
\hline & $\begin{array}{l}\text { social affiliation - it does not matter which social class the defendant is } \\
\text { (teacher, farmer, engineer, carpenter, etc.). }\end{array}$ \\
\hline & $\begin{array}{l}\text { the acquaintance of the interlocutors - the acquaintance of the defendant } \\
\text { to the presiding judge (friend or foe, relative, etc.) or unfamiliarity does } \\
\text { not prevent him from acting in accordance with the law, i.e. it is } \\
\text { completely insignificant. }\end{array}$ \\
\hline & $\begin{array}{l}\text { age of communicators - whether the defendant is an adult or an adult is } \\
\text { irrelevant in this appeal. }\end{array}$ \\
\hline & $\begin{array}{l}\text { their gender - both men and women can participate in the case as } \\
\text { defendants, Insignificant in this appeal. }\end{array}$ \\
\hline & $\begin{array}{l}\text { the place of residence, the stylistic situation, the character of the } \\
\text { communicators, etc., are as insignificant as the above. }\end{array}$ \\
\hline
\end{tabular}

Researcher H. Yuldasheva in her research distinguishes two types of social adaptation in language units:

1. The social nature of naming.

2. Social specificity of application [2.14].

\section{CONCLUSION}

In this sense, it is possible to distinguish between social lexicon and social speech.

Social lexicon served to name the society and to express its features. In order to explain the socially oriented vocabulary (names), we cite Article 429 of the Code of Criminal Procedure. "The clerk of the court shall provide information on whether the public prosecutor, 
the public prosecutor, the defendant, the defense counsel, the public defender, as well as the victim, the civil plaintiff, the civil defendant or their representatives have appeared in court. It is then checked whether an interpreter, witnesses, experts and specialists have appeared in court. The secretary will explain why those who were not present did not come "(Part 1). The composition of the court listed in this article: The words of the clerk of the court, the public prosecutor, the public prosecutor, the defendant, the defense counsel, the public defender, the victim, the civil plaintiff, the civil defendant and their representatives, the interpreter, witnesses, experts, experts are social terms.

Social speech - serves to show the speech characteristics of the representatives of the social position. "The social character of speech is more socially symbolic than language and other features of speech. Due to the fact that common language units (speech, sentence, sentence forms, context - I.X.) are not often used in one group, it is expedient to differentiate them according to their use of language units "(partial edition - I.X.). The following linguistic units (forms of speech) quoted from the speech of the presiding judge, the public prosecutor, and the defendant prove these points.

1. In the speech of the chairman: "To be found guilty", "to be punished", "to be imprisoned", "to be found not guilty", "to be released from the courtroom";

2. In the speech of the public prosecutor: "I ask you to impose a sentence, "he said"; in the speech of the defense attorney: "Dear Judge and People's Advisers! ”," I plead not guilty ", " I ask you to acquit me and release me from the courtroom ";

3. In the speech of the defendant (s) (last word): "Forgive me," "I'm sorry for what I did," "How I look at my parents' faces," “I won't do it again," "Give me a chance," "I apologize," “I won't be returned," “I'm in a bad family situation," "I ask you to impose a different type of punishment" and the use of expressions such as can be assessed as socially oriented speech. Studies say there are formal or informal conditions for communication. While informal conditions are warm, simple, cordial, formal conversations occur more often in the workplace (in the courthouse I.X.) and, as noted, appear more cool. In formal conversations, it is emphasized that naming by surname, first name, patronymic (in social terms, according to social status - I.X.) is the predominance of direct expression of purpose. [10.43]

"Every person has a duty to speak normatively in accordance with his or her social capacity. This speech provides information about the social function performed by the speaker. It can also be thought of as a social adaptation of speech"[11. 83]. Accordingly, the speech of the presiding judge (negotiator), the introductory speech of the public prosecutor (prosecutor), the defense speech of the defense counsel (lawyer) shall be manifested in accordance with the above-mentioned norms. In addition, elements of the social character of the speech are observed in the speech of the clerk of the court, witnesses, public prosecutor, public defender and their representatives, experts, specialists, translators.

\section{REFERENCES}

1. Mahmudov N. Speech culture and other sciences // Uzbek language and literature. Tashkent: 2007. №1.

2. Yuldasheva X. Sociolinguistic study of Uzbek historical novels. Filol.fan.b.falsafa doc. ... (PhD) diss . Tashkent: 2017.

3. Bondaletov V.D. Sotsialnaya linguistics. Moscow: Prosveshchenie. 1987.

4. Normurodov R. Sociolinguistics. Termiz: 2008.

5. Ne'matov H; Joraeva B. Sociolinguistics. Buxoro: 2004. 
6. Mahmudov N; Mirtojiev M. Language and culture. Tashkent: Uzbekistan. 1992; Mahmudov N. Language. Tashkent: Writer. 1997.

7. Iskandarova Sh. Forms of communication of the Uzbek speech habit: Filol.fan.nomz. ... diss. Samarkand: 1993; Muminov S.M. Sociolinguistic features of Uzbek communication behavior: Filol.fan. d-ri ... diss. Tashkent: 2000; Sulaymonov M. Sociolinguistic features of Uzbek manuscripts: filol.fan.nomz. ... diss. Tashkent: 2009; Rasulov Q. Functional adaptation of Uzbek communication behavior: filol.fan.nomz. ... diss. Tashkent: 2008; Qurbonova M. Sociolinguistic study of Uzbek children's lexicon: filol.fan.nomz. ... diss. Tashkent: 2009; Raupova L. Sociopragmatic study of polypredicative units in dialogic discourse: Filol.fan. d-ri ... diss. Tashkent: 2012; Yuldasheva $X$. Sociolinguistic study of Uzbek historical novels. Filol.fan.b.falsafa doc. ... (PhD) diss . Tashkent: 2017.

8. Belikov V.I; Krysin L.P. Sociolinguistics. Moscow: 2001.

9. Karimov S; Mamatov H; Buriev I. The speech culture of a lawyer. Tashkent: 2004.

10. Iskandarova Sh. Forms of communication of the Uzbek speech habit. Filol.fan.nomz. diss ... Samarkand: 1993.

11. Hakimov M. Pragmatic interpretation of the text in Uzbek language: Filol.fan. d-ri ... diss. Tashkent: 2001. 